was excellent. Infants do not respond well to purified polysaccharide antigens of pneumococci, meningococci, or Haemophilus influenzae. Although $S$ typhi $\mathrm{O}$ is a polysaccharide, infants responded to it as well as older children, probably because it was presented as a whole cell antigen. $S$ typhi $\mathrm{H}$ is protein, and the immune response was better.

New vaccines against typhoid fever are at various stages of development and evaluation. Until better vaccines are available the heat killed $S$ typhi vaccine may be given, either subcutaneously or intradermally, starting at 6 months of age.

This study was conducted under the auspices of the
Epidemiology Resource Centre supported by the Ford Foundation, New Delhi.

1 Christie AB. Infectious diseases: epidemiology and clinical practice. Vol 1. 4th ed. Edinburgh: Churchill Livingstone, 1987:100-64.

2 Crietanovic B, Uemura $K$. The present status of field and laboratory studies of twphoid and paratsphoid vaccines with special reference to studies sponsored by WHO. Bull WHO 1965;32:29-36.

3 Rao MN, Sundari B, Shyamalamba CH, Rao PG. A study of antibody response to $T A B$ vaccine in school children and its relationship to nutritional status. Indiun Pediuer 1977:14:271-4.

+ Ramakrishnan PS, Norman EJ, Krishnamurthy KA. A study of antibody response to $\mathrm{TAB}$ vaccination by subcutaneous and intradermal routes in response to TAB vaccination by subcutaneous and
urban school children. Indian Pediatr 1978;15:641-3.

5 Cruickshank R, Duguid JP. Marmion BP, Swain RHA. Medical microbiology. Vol 3. 12th ed. Edinburgh: Churchill Livingstone, 1975:403-19.

Accepled 27 September 1988

\section{Metabolic Unit, \\ Department of Chemical Pathology and Human Metabolism, Royal Free Hospital and School of Medicine, London NW3 2PF \\ V A Fonseca, MD, senior registrar \\ M Thomas, PHD, principal hospital biochemist \\ P Dandona, FRCP, director}

Department of Radiology,

Royal Free Hospital and

School of Medicine

R Dick, FRCR, consultant radiologist

Vascular Clinic, Royal Free Hospital and School of Medicine

G Hamilton, FRCS, consultant surgeon

Correspondence to: $\mathrm{Dr}$ Dandona.

\section{Serum gonadotrophin concentrations in men with peripheral vascular disease and impotence}

\section{A Fonseca, M Thomas, R Dick, G Hamilton, P Dandona}

Impotence is a common problem in men with peripheral vascular disease. It is usually attributed to impaired blood supply to the penis due to arterial atherosclerosis': and is associated with hypercholesterolaemia, smoking, and diabetes. We measured testicular function to test whether such patients may also have testicular ischaemia and hypogonadism.

\section{Patients, methods, and results}

Thirty two patients with peripheral vascular disease (age range 39-79) who had stable marital relationships and were not taking drugs which induce impotence were divided into two groups: those who complained of impotence (group $1 ; \mathrm{n}=20$ ) and those who claimed to have normal sexual activity (group $2 ; \mathrm{n}=12$ ). We also studied a control group of 20 men with minor illnesses attending a day centre or hospital outpatient department (age range 39-79).

Serum testosterone, ${ }^{+}$luteinising hormone, and follicle stimulating hormone concentrations were measured by radioimmunoassay and sex hormone binding globulin concentration was measured by
Serum concentrations of testosterone, corrected testosterone, sex hormone binding globulin, luteinising hormone, and follicle stimulating hormone in patients with peripheral vascular disease and controls

\begin{tabular}{|c|c|c|c|c|}
\hline & \multicolumn{4}{|c|}{ Patients with peripheral vascular disease } \\
\hline & All & $\begin{array}{c}\text { Group 1 } \\
\text { (impotent) }\end{array}$ & $\begin{array}{c}\text { Group 2 } \\
\text { (not } \\
\text { impotent) }\end{array}$ & Controls \\
\hline No in group & 32 & 20 & 12 & 20 \\
\hline Age (range) (years) & $\begin{array}{c}67 \\
(38-79)\end{array}$ & $\begin{array}{c}68 \\
(38-79)\end{array}$ & $\begin{array}{c}65 \\
(48-78)\end{array}$ & $\begin{array}{c}69 \\
(39-79)\end{array}$ \\
\hline No with diabetes & 7 & 4 & 3 & \\
\hline No with hypertension & 19 & 11 & 8 & \\
\hline Median (range) ankle:brachial pressure index & $\begin{array}{c}0 \cdot 64 \\
(0 \cdot 5-0 \cdot 8)\end{array}$ & $\begin{array}{c}0.63 \\
(0.5-0.8)\end{array}$ & $\begin{array}{c}0.66 \\
(0.55-0 \cdot 75)\end{array}$ & \\
\hline Median (range) total testosterone $(\mathrm{nmol} / \mathrm{l})$ & $\begin{array}{c}17 \cdot 4 \\
(10 \cdot 1-30 \cdot 0)\end{array}$ & $\begin{array}{c}19 \\
(10 \cdot 1-30 \cdot 0)\end{array}$ & $\begin{array}{c}17 \cdot 1 \\
(12 \cdot 0-21 \cdot 9)\end{array}$ & $\begin{array}{c}18 \cdot 3 \\
(10 \cdot 3-38 \cdot 1)\end{array}$ \\
\hline Median (range) sex hormone binding globulin ( $\mathrm{nmol} / \mathrm{l})$ & $\begin{array}{c}41 \\
(13-73)\end{array}$ & $\begin{array}{c}47 \\
(13-73)\end{array}$ & $\begin{array}{c}32 \\
(14-58)\end{array}$ & $\begin{array}{c}44 \\
(16-89)\end{array}$ \\
\hline Median (range) corrected testosterone $\neq(\mathrm{nmol} / \mathrm{l})$ & $\begin{array}{c}12 \cdot 0 \\
(7 \cdot 0-25 \cdot 7)\end{array}$ & $\begin{array}{c}11 \cdot 9 \\
(7 \cdot 0-25 \cdot 6)\end{array}$ & $\begin{array}{c}12 \cdot 2 \\
(7 \cdot 7 \cdot 25 \cdot 7)\end{array}$ & $\begin{array}{c}15 \cdot 2 \\
(6 \cdot 1-30 \cdot 0)\end{array}$ \\
\hline Median (range) luteinising hormone (IU/1) & $\begin{array}{c}7 \cdot 9 \\
(2 \cdot 2-50 \cdot 0)\end{array}$ & $\begin{array}{c}9 \cdot 9+\star \star \\
(5 \cdot 5-50 \cdot 0)\end{array}$ & $\begin{array}{c}5 \cdot 7 \\
(2 \cdot 2-8 \cdot 3)\end{array}$ & $\begin{array}{c}5 \cdot 7 \\
(2 \cdot 7-18 \cdot 2)\end{array}$ \\
\hline Median (range) follicle stimulating hormone (IU/l) & $\begin{array}{c}5 \cdot 9 \\
(0 \cdot 9-20 \cdot 0)\end{array}$ & $\begin{array}{c}7 \cdot 6^{\star} \\
(2 \cdot 0-20 \cdot 0)\end{array}$ & $\begin{array}{c}4 \cdot 5 \\
(0 \cdot 9-7 \cdot 8)\end{array}$ & $\begin{array}{c}5 \cdot 0 \\
(1 \cdot 1-13 \cdot 6)\end{array}$ \\
\hline
\end{tabular}

${ }^{\star} \mathrm{p}<0.05$ and $\mathrm{tp}<0.002$ compared with group $2 .{ }^{\star \star} \mathrm{p}<0.01$ compared with controls.

$\ddagger$ Corrected to sex hormone binding globulin concentration of $30 \mathrm{nmol} / \mathrm{l}$. immunoradiometric assay. 5 Serum testosterone concentration was corrected to a sex hormone binding globulin concentration of $30 \mathrm{nmol} / \mathrm{l}$ (midpoint of the reference range for men)

Arteriography was performed in 17 of the impotent patients, and atheromatous disease was classified as aortoiliac in two, femoral in seven, distal in one, and diffuse in seven. Statistical analysis was carried out with the Mann-Whitney U test for non-parametric data and the $\chi^{2}$ test.

Serum testosterone, sex hormone binding globulin, and corrected testosterone concentrations were similar in the three groups (table). Serum luteinising hormone concentration was significantly higher in group 1 than in group $2(p<0 \cdot 01)$. Ten of the 20 patients in group 1 had luteinising hormone concentrations above $10 \mathrm{IU} / \mathrm{l}$ compared with three of the 20 controls $(\mathrm{p}<0.02)$ and none of the patients in group $2(\mathrm{p}<0.01)$. Serum follicle stimulating hormone concentration was significantly higher in group 1 than group $2(p<0 \cdot 05)$. Follicle stimulating hormone concentration was above $10 \mathrm{IU} / \mathrm{l}$ in eight of the 20 patients in group 1 compared with three of the 20 controls $(p<0.02)$ but in none of the patients in group 2. Similar differences were observed when patients and controls under the age of 70 were considered separately.

\section{Comment}

Serum concentrations of luteinising hormone and follicle stimulating hormone were significantly higher in men with peripheral vascular disease who were impotent than in men with peripheral vascular disease who had normal sexual activity and in controls. There was no difference in the concentration of testosterone and sex hormone binding globulin between the normal controls and either group of men with peripheral vascular disease, or in the concentrations of gonadotrophins between normal subjects and the men with peripheral vascular disease and normal sexual function. Confining the analysis to those aged less than 70 did not alter the results. Raised luteinising hormone and follicle stimulating hormone concentrations in the impotent patients were similar to those found in controls aged over 70 .

These data suggest that a state of compensated hypogonadism may exist in men with peripheral vascular disease who are impotent. The increases in the concentrations of luteinising and follicle stimulating hormones were significant but the concentrations were only in the range associated with postmenopausal women $(>10 \mathrm{IU} / \mathrm{l})$ in 10 of the 20 patients, of whom six were aged under 70 . The role of compensated hypogonadism in the pathogenesis of these patients' impotence is therefore uncertain and can be determined only by a trial of testosterone treatment. This would have to be conducted cautiously as the 
treatment can promote prostatic carcinoma in the elderly. The pathogenesis of hypogonadism in patients with peripheral vascular disease is probably related to atherosclerosis of the testicular and renal arteries and the aorta.

We thank Dr N Carr for obtaining the control serum samples and St Thomas's Hospital and Chelsea Hospital for Women for supplying reagents for radioimmunoassay.
1 Lerich R. Des obliterations arterielles hautes comme cause d'une insufficiance circulatoire des membres inferieurs. Bull Soc Chirurgie 1923;49:1404

Michal V. Arterial disease as a cause of impotence. $\mathcal{f}$ Clin Endocrinol Metab 1982;11:725-48.

3 Virag R, Bouilly P, Fevdman D. Is impotence an arterial disorder? A study of arterial risk factors in 440 impotent men. Lancet 1985; ; : 181-4

4 Wheeler MJ, Luther F. Development of testosterone radioimmunoassay for routine use. In: Hunter WM, Corrie JET, eds. Immunoassay for clinical routine use. In: Hunter WM, Corrie JET, eds. Immunas

5 Hammond GL, Langley MS, Robinson PA. A liquid phase immunoradiometric assay (IRMA) for human sex hormone binding globulin (SHBG). I Steroid Biochem 1985;23:451-60

(Accepted 11 October 1988)

\title{
Mortality from leukaemia among relatives of patients with cystic fibrosis
}

\author{
L N Al-Jader, R R West, M C Goodchild, \\ P S Harper
}

University of Wales

\section{College of Medicine} Cardiff CF4 4XN L N Al-Jader, MB, clinical assistant in medical genetics R R West, PHD, senior lecturer in epidemiology and community medicine M C Goodchild, MD, associate specialist, cystic fibrosis unit P S Harper, FRCP, professor of medical genetics

Correspondence to: Dr Al-Jader.
Cystic fibrosis is an inherited autosomal recessive disease, the gene for which has been localised on chromosome 7.' As part of a systematic clinical and molecular genetic study of families of patients with cystic fibrosis in Wales we obtained data on the prevalence of other diseases. We report here our findings on mortality from leukaemia.

\section{Patients, methods, and results}

Altogether 130 families of patients with cystic fibrosis were studied. No bias was exercised by selection of patients, who were seen when they attended for routine clinical follow up. Cystic fibrosis had been diagnosed after typical clinical features were seen and at least one sweat test gave a positive result. Detailed family histories were obtained, including vital state, all diseases, and causes of death. Diagnoses of leukaemia were verified from original haematological data.

We studied 149 patients, 260 parents, 119 siblings without cystic fibrosis, 57 half siblings without cystic fibrosis, 743 aunts and uncles, and 518 grandparents. Information was incomplete for $7 \%$ of aunts and uncles and $9 \%$ of grandparents; they were assigned according to the age distribution of the appropriate group. All relatives who had leukaemia had died.

The expected numbers of deaths from leukaemia were calculated by reference to age specific mortalities for England and Wales using age specific person years at risk in each of the six groups of relatives. These figures were then compared with the observed number of deaths with an exact binomial probability test. As a check comparisons were made for mortalities from all causes.

Seven relatives of patients with cystic fibrosis had died from leukaemia: two parents (one mother aged 37, who had had acute myelomonocytic leukaemia; and one father aged 42, acute promyelocytic); one half sibling without cystic fibrosis (a girl aged 2, acute lymphoblastic); one aunt (aged 55, acute myeloid); one uncle (aged 31/2, acute lymphoblastic); and two grandfathers (one aged 73, acute myeloid; and one aged 78 , acute myelomonocytic). These patients with leukaemia were from different families, apart from the younger grandfather and aunt, who were father and daughter. The cystic fibrosis carrier state was known for the two parents (obligatory carriers) but not for the other patients with leukaemia. The affected half sibling showed no visible abnormality of chromosome 7 .
The table shows the expected and observed numbers of deaths from leukaemia. Overall these were $2 \cdot 19$ and $7(\mathrm{p}=0.007)$, and for parents only they were $0 \cdot 18$ and 2 $(p=0.014)$. Mortality from all causes among relatives generally agreed with predicted rates, whereas patients with cystic fibrosis showed the expected increase $(p=0 \cdot 001)$.

Expected and observed numbers of deaths from leukaemia among patients with cystic fibrosis and their relatives

\begin{tabular}{lccc}
\hline \multicolumn{1}{c}{ Relationship } & $\begin{array}{c}\text { No of } \\
\text { subjects } \\
\text { studied }\end{array}$ & $\begin{array}{c}\text { No of } \\
\text { deaths } \\
\text { expected }\end{array}$ & $\begin{array}{c}\text { No of } \\
\text { deaths } \\
\text { observed }\end{array}$ \\
\hline Patient & 149 & $0 \cdot 030$ & \\
Parent & 260 & $0 \cdot 181 \dagger$ & $2 \dagger$ \\
Sibling without cystic fibrosis & 119 & $0 \cdot 030$ & \\
Half sibling without cystic fibrosis & 57 & $0 \cdot 011$ & 1 \\
Aunt or uncle & 743 & $0 \cdot 584$ & 2 \\
Grandparent & 518 & $1 \cdot 353$ & 2 \\
\hline & 1846 & $2 \cdot 189 \ddagger$ & $7 \ddagger$
\end{tabular}

^Expected according to age distribution, age specific person years at risk, *xpected according to age distribution, age specific person years at risk,
and age specific mortality from leukaemia in England and Wales 1979-85 (Office of Population Censuses and Surveys). $t \mathrm{p}=0.014$. $\dagger \mathrm{p}=0 \cdot 014$.
$\neq \mathrm{p}=0.007$.

\section{Comment}

In this study leukaemia was not found among the patients with cystic fibrosis, though such cases have been recorded.2 The cystic fibrosis gene and the met-oncogene are closely linked on the long arm of chromosome 7 , being mapped to bands $7 \mathrm{q} 31$ and 7q21-31 respectively. ${ }^{3}$ This region is associated with non-random chromosomal deletions, which have been observed in some patients with acute non-lymphocytic leukaemia.

Chromosomal studies in the myelodysplastic syndrome and acute non-lymphocytic leukaemia have shown variable changes due to monosomy 7 or partial deletions of the long arm of 7; the met-proto-oncogene is within this deleted segment. ${ }^{4}$ Additionally, $7 \mathrm{q} 32$ has been classified as one of the most common fragile sites. ${ }^{5}$

We suggest that a gene linked closely to the cystic fibrosis gene, possibly the met-oncogene, may predispose those who carry the cystic fibrosis gene to develop leukaemia. Further somatic events may be necessary for leukaemic transformation. Although only seven deaths due to leukaemia occurred, this was significant. It will be important to know if other centres can confirm this finding.

We thank Professor A Jacobs of the department of haematology, University Hospital of Wales, Cardiff, for helpful discussions.

1 White R, Woodward S, Leppert M, et al. A closely linked genetic marker for cystic fibrosis. Nature 1985;318:382-4.

Biggs B, Vaughan W, Sanger W, Purtilo D. Cystic fibrosis complicated by acute leukaemia. Cancer 1986;57:2441-3.

3 Dean M, Park M, Le Beau M, et al. The human met oncogene is related to tyrosine kinase oncogenes. Nature 1985;318:385-8.

4 Kere J, Ruutu T, De la Chapelle A, et al. Monosomy 7 in granulocytes and monocytes in myelodysplastic syndrome. N Engl f Med 1987;316:499-503. 5 Tsui L. Genetic markers on chromosome 7. F Med Genet 1988;25:294-306

(Accepted 4 October 1988 